\title{
Long-Term Effects of Corruption Control and Economic Freedom on Economic Growth
}

\author{
Natanael Soares Leite, Francisco Germano Carvalho Lucio, Roberto Tatiwa Ferreira \\ Federal University of Ceará-UFC/CAEN, Fortaleza, Brazil \\ Email: natana el soaresleite@gm ail.com, germanocarvalho@caen.ufc.br,rtf2@uol.com.br
}

How to cite this paper: Leite, N.S., Lucio, F.G.C. and Ferreira, R.T. (2019) Long-Term Effects of Corruption Control and Economic Freedom on Economic Growth. Theoretical Economics Letters, 9, 2965-2974. https://doi.org/10.4236/tel.2019.98183

Received: October 17, 2019

Accepted: December 10, 2019

Published: December 13, 2019

Copyright (c) 2019 by author(s) and Scientific Research Publishing Inc. This work is licensed under the Creative Commons Attribution International License (CC BY 4.0).

http://creativecommons.org/licenses/by/4.0/

\begin{abstract}
Theoretical models and empirical evidence show that corruption control and economic openness have effects on economic growth. This paper aims to estimate the long-term effects of the anti-corruption effort and economic freedom on economic growth in a sample of 121 countries. We use autoregressive distributed lag (ARDL) models and estimation techniques appropriate to the case where there is a correlation between cross-section errors possibly generated by spillover effects. Besides, estimates of ARDL models are consistent even with endogenous regressors and integrated variables. The results indicate that economic growth of a country can be positively and significantly affected by the long-term corruption control and economic freedom.
\end{abstract}

\section{Keywords}

Economic Growth, Control of Corruption, Economic Freedom, Autoregressive Models

\section{Introduction}

Corruption, whether public or private, is a worldwide problem. This phenomenon diverts part of the available resources for investment, generating both inefficiency and waste in public spending. According to [1], corruption has negative effects on a nation's wealth and economic growth, discouraging new investments and creating uncertainty over private and social rights. This uncertainty acts as a cost on entrepreneurship, decreasing return on investment and increasing its variation, which discourages investment activities. Similar results are presented in [2] [3] [4].

Additionally, several studies such as [5] [6] [7] [8] [9] show that corruption can reduce the level of human capital. The reasoning behind this is that corrup- 
tion encourages inefficient allocation of government resources in areas with great bribery capacity, diverting them from other important sectors such as education. However, there are other studies that indicate a positive effect on economic growth [10]-[16] From this perspective, corruption would act as a way to lessen bureaucracy, which would increase the economy's efficiency, thereby reducing barriers to investment and economic growth.

There is a possible relationship between economic freedom and corruption and between economic growth and economic freedom. Results from [17] [18] [19] point out a negative relationship between these variables. However, [20] shows that an increase in economic freedom does not reduce corruption in more corrupt economies. In such cases, greater economic freedom may increase corruption problems, indicating that nations respond differently to different levels of economic freedom.

Regarding economic freedom and growth, [21] shows that there is a strong positive relationship between economic freedom and economic growth. Moreover, they show that economic freedom has substantially more explanatory power than political freedom and civil liberties as determinants of economic growth. According to [22], economic freedom is associated with higher levels of income, income growth, human development rates, and lower unemployment.

Few studies analyze the relationship between this set of variables. An example is [23], which estimates a panel VAR (PVAR) and finds evidence that corruption and a low level of economic freedom have a negative effect on national income.

Most empirical evidence on this subject does not use a long-term analysis method. Corruption may reduce bureaucracy and positively affect short-term economic activity in some contexts, but may have negative effects on long-term growth. Thus, the present work intends to fill this gap by estimating the long-term effects of efforts against corruption and economic freedom on economic growth from 121 countries for the period 2002-2015.

We use autoregressive distributed lagged (ARDL) models and estimation techniques that take into account the correlation between cross-sectional errors, possibly generated by spillover effects, an approach that has not been used by other studies so far.

In addition to this introduction, this work has five more sections. The second section presents the literature review. The third section presents the methodology and data. The results are presented in the fourth section and discussed in the fifth section. Finally, we present our conclusions in the last section.

\section{Literature Review}

\subsection{Corruption and Growth}

There is no consensus on the effects of corruption on economic growth. On the one hand, corruption has negative effects on the economic growth of an economy through the "sand the wheels" hypothesis. On the other hand, the "grease the wheels" hypothesis argues that corruption in highly regulated countries can off- 
set the effects of heavy bureaucracy and stimulate the economy by reducing barriers to investment [24].

In the first stream, the results found in [1] suggest that corruption directly hinders economic growth, making investment difficult. The authors use an open economy version of the endogenous growth model with international capital mobility. In the model, corruption negatively affects host country investment stocks and growth by the uncertainty caused by corruption. The authors empirically verify this hypothesis using a sample of 142 countries from 1994-2014 and GMM methods. Similar results are presented in [16], where data from 19 Asian Countries over the 2014-2015 period using D-GMM and quantile regression are used. [25] Investigate the effects of corruption in Nigeria and report that corruption is perverse and dangerous for the nation.

In [26] dynamic panel data models are estimated for a sample of 103 countries observed from 1996 to 2015. The results suggest positive effects of corruption control on economic growth performance.

The work of [9] reports that corruption reduces the level of human capital and the share of private investment. The author states that the most important channel through which corruption affects economic growth is political instability.

In the second stream, [24] analyzes the interaction between aggregate efficiency, corruption and other governance dimensions for a panel of 69 developed and developing countries from 1970-1998. Their results show that corruption is less detrimental to efficiency in countries where institutions are less effective. In countries where institutions are extremely ineffective, there may be a positive correlation between corruption and efficiency.

The work of [27] estimates the effects of corruption on foreign direct investment (FDI) for a sample of 73 developed and least developed countries in the period of 1995-1999. Their results show a positive short-term impact of corruption on the FDI and a long-term positive impact of corruption on host country's attractiveness for foreign investors.

In [16] the effect of corruption on economic growth is estimated in a sample of 19 Asian countries from 2004 to 2015. According to the author, corruption increases economic growth in countries with less economic freedom, but the impact of the beneficial effect of corruption diminishes as economic freedom increases.

\subsection{Economic Freedom and Growth}

According to the proponents of the new growth theory, see [28] for example, the quality of institutions and the economic environment are important for economic growth. For [29] more political freedom fosters economic freedom that stimulates economic growth. However, analyzing a panel of countries, [30] finds weak evidences of a negative correlation between democracy and growth. [31], using a different sample reports that democracy is unrelated to growth, but political stability and credibility are important determinants of growth. 
[32] proposed a comprehensive index of economic freedom independent of political freedom. The authors report a positive and significant correlation between economic freedom and growth. Several works that use the broad index of economic freedom have similar results. For example, [21] shows that economic freedom is even more important than traditional growth factors, such as investment and human capital, and more potent than political freedom. The authors also report that there is no evidence of a reverse causality of growth and economic freedom.

[33] uses various indicators of economic freedom in a sample of 80 countries from 1975-1990 and conclude that higher economic freedom promotes growth, but as in [21], there is no reverse effect.

[34] investigates the relationship between economic freedom and economic growth in a sample of 50 US states from 1981 to 2004 . The results point to a positive relationship among these variables, but the components of economic freedom affect growth in different ways.

According to [35] their study presents two contributions. The first contribution of the paper is to identify which indicators of economic freedom make the greatest contributions to growth. The second contribution of the article is to examine the effects of economic freedom, public spending and fiscal balance on growth in transition countries in the period 1994-2007 and after the financial crisis (2008-2009). The results generally show that economic freedom leads to higher growth rates largely by stimulating investment.

\section{Methodology and Data}

\subsection{The ARDL Model}

Several studies such as [36] [37] [38] show that autoregressive distributed lag models (ARDL) are useful for estimating long-term effects. These estimates are consistent even if there are endogenous regressors, stationary series, or integrated (unit root) processes. An $\operatorname{ARDL}$ model $(p, q)$ can be expressed as follows:

$$
y_{i t}=c_{i}+\sum_{l=1}^{p} \varphi_{i l} y_{i, t-l}+\sum_{l=0}^{q} \beta_{i l}^{\prime} x_{i, t-l}+\varepsilon_{i t}
$$

The estimate of the long-term effects is obtained by

$$
\hat{\theta}_{l}=\frac{\sum_{l=0}^{q} \hat{\beta}_{i l}}{1-\sum_{l=0}^{p} \hat{\varphi}_{i l}}
$$

However, a series of spillover effects, caused for example by human capital or financial crises can generate a correlation between cross-section errors of growth equations, undermining the inferences of a panel data model. In these cases, cross-sectional averages of regressors are added to the ARDL model (CS-ARDL), as suggested by [39]. This model can be represented as: 


$$
y_{i t}=c_{i}+\sum_{l=1}^{p} \varphi_{i l} y_{i, t-l}+\sum_{l=0}^{q} \beta_{i l}^{\prime} x_{i, t-l}+\sum_{l=0}^{z} \alpha_{i l}^{\prime} \bar{z}_{i, t-l}+\varepsilon_{i t}
$$

where $z=\left[T^{1 / 3}\right], \bar{z}_{t}=\left(\bar{y}_{t}, \bar{x}_{t}^{\prime}\right), \bar{y}_{t}=N^{-1} \sum_{i=1}^{N} y_{i t}$ e $\bar{x}_{t}=N^{-1} \sum_{i=1}^{N} x_{i t}$. Equation (3) is estimated by the common correlated effects approach. It is suggested by [40] and expanded by [41].

\subsection{Data}

The variables are corruption control $(c p)^{1}$, also used in [1] [42], real GDP per capita (2010 US dollars), and economic freedom index. The former two are collected from the World Bank, and the latter is collected from the Fraser Institute ${ }^{2}$. The sample consists of 121 countries recognized by the United Nations (UN), from 2002 to 2015. Although the UN recognizes 193 countries, many of them have no data available for all variables of the chosen range.

Table 1 presents the descriptive statistics of the aforementioned variables. Countries with higher average income per capita have higher averages of both corruption control and economic freedom. On the other hand, countries with lower incomes have a lower average of both corruption control and economic freedom. Additionally, it is observed a greater deviation from the average in this group.

\section{Results}

Table 2 presents the results for three ARDL model specifications. In model (a) the only regressor is the variable degree of economic freedom, in (b) only the corruption control variable, and finally, in (c) both variables are included. Estimates of the long-term effects of the degree of economic freedom and/or corruption control on economic growth are presented. These models are estimated for $z=\left[T^{1 / 3}\right]$ time lags $(p=q=z=(1,2))$.

These early results suggest that there is some influence on the degree of economic freedom and the degree of corruption control over economic growth. In model (a), the coefficient that measures the long-term effects of economic freedom on growth has values ranging from 0.013 to 0.015 . In model (b), there is a positive and statistically significant relationship of corruption control over economic growth around 0.001 . In the model (c) these variables are not statistically significant.

However, the test statistics (CD) presented in [45] reject the null hypothesis of independence between cross-sections in all specifications. For this reason, models that include the cross-sectional averages (CS-ARDL) are estimated following the methodology proposed by [39]. These new results are in Table 3. CD statistics do not reject the null hypothesis of independence between cross-sections

${ }^{1}$ The $\mathrm{CP}$ measures the anti-corruption efforts of one country relative to other countries ranging from 0 to 100 . For more details about this index see [23]. The corruption perception index is not suitable for this paper due to missing information at the beginning of the sample.

${ }^{2}$ The Economic Freedom of the World - EFW index ranges from 0 to 10, where higher values represent higher levels of economic freedom. For more information of the EFW index see [43] [44]. 
Table 1. Descriptive Statistics by quartile of the average GDP of the countries.

\begin{tabular}{|c|c|c|c|}
\hline & GDP per capita (U\$2010) & Control of Corruption & Economic Freedom \\
\hline \multicolumn{4}{|c|}{ Part $1^{(i)}$} \\
\hline Mean & 839.7841 & 23.21198 & 5.99659 \\
\hline Standard deviation & 458.5806 & 15.83528 & 0.8297683 \\
\hline $\mathrm{CV}$ & 0.5460696 & 0.682203 & 0.1383734 \\
\hline Asymmetry & 0.9453976 & 0.7969979 & -0.6952659 \\
\hline Minimum & 219.19 & 0 & 2.93 \\
\hline Maximum & 2428.78 & 75.48 & 7.57 \\
\hline \multicolumn{4}{|c|}{ Part $2^{(\text {ii) }}$} \\
\hline Mean & 3869.707 & 38.96807 & 6.535833 \\
\hline Standard deviation & 1398.464 & 16.98863 & 0.7074648 \\
\hline $\mathrm{CV}$ & 0.3613875 & 0.4359628 & 0.108244 \\
\hline Asymmetry & 0.555083 & 0.1950256 & -0.7481322 \\
\hline Minimum & 1326.24 & 0.51 & 4.4 \\
\hline Maximum & 7612.02 & 84.85 & 7.69 \\
\hline \multicolumn{4}{|c|}{ Part $3^{(\mathrm{iii})}$} \\
\hline Mean & 13013.46 & 61.42305 & 6.933381 \\
\hline Standard deviation & 4734.271 & 19.78453 & 0.8085445 \\
\hline $\mathrm{CV}$ & 0.3637981 & 0.3221027 & 0.1166162 \\
\hline Asymmetry & 0.5875943 & -0.9473012 & -1.801913 \\
\hline Minimum & 5383.8 & 4.33 & 2.92 \\
\hline Maximum & 25511.47 & 92.89 & 8.15 \\
\hline \multicolumn{4}{|c|}{ Part $4^{(\mathrm{iv})}$} \\
\hline Mean & 45472.26 & 89.16738 & 7.708119 \\
\hline Standard deviation & 17599.36 & 10.70752 & 0.514882 \\
\hline $\mathrm{CV}$ & 0.387035 & 0.1200834 & 0.066797 \\
\hline Asymmetry & 1.582774 & -1.604113 & 0.475092 \\
\hline Minimum & 19796.07 & 50.96 & 6.36 \\
\hline Maximum & 111968.4 & 100 & 9.19 \\
\hline
\end{tabular}

Quartiles of the average income per capita: (i) Countries below the 1st quartile; Countries between 1st and 2nd quartile; (iii) Countries between the 2 nd and 3rd quartile; (iv) Countries above the 3rd quartile.

and the parameters of long-term effects are statistically significant in all cases, including model (c) that uses both economic freedom and corruption control.

\section{Discussion}

Our results indicate a long-term positive relationship between corruption control and economic growth, corroborating the "sand the wheels" hypothesis. Similar results are found in [26], which also uses the corruption control variable, and is lined with the results of [1] [9] [24] [25], among others.

Concerning economic freedom, our results corroborate the work of [21] [22] [29] [32], and also indicate a positive long-term relationship between 
Table 2. Table Estimated Fixed Effect (FE) of the long-term effect based on the ARDL approach, 2002-2015.

\begin{tabular}{|c|c|c|c|c|c|c|}
\hline & \multicolumn{6}{|c|}{ ARDL (FE) } \\
\hline & \multicolumn{3}{|c|}{$1 \mathrm{Lag}$} & \multicolumn{3}{|c|}{2 Lags } \\
\hline & (a) & (b) & (c) & (a) & (b) & (c) \\
\hline \multirow{2}{*}{$\hat{\theta}_{\text {free }_{i t}}$} & $0.015^{*}$ & & 0.013 & $0.013^{*}$ & & 0.011 \\
\hline & $(0.059)$ & & $(0.111)$ & $(0.074)$ & & $(0.147)$ \\
\hline \multirow{2}{*}{$\hat{\theta}_{c p}$} & & $0.001^{\star *}$ & 0.001 & & $0.001^{* *}$ & 0.001 \\
\hline & & $(0.017)$ & $(0.048)$ & & $(0.016)$ & $(0.044)$ \\
\hline \multirow{2}{*}{$\hat{\lambda}$} & $-0.795^{* * *}$ & $-0.790^{\star * *}$ & -0.800 & $-0.905^{* * *}$ & $-0.894^{\star * \star}$ & -0.916 \\
\hline & $(0.000)$ & $(0.000)$ & $(0.000)$ & $(0.000)$ & $(0.000)$ & $(0.000)$ \\
\hline Test CD & $88.94^{\star * *}$ & $87.12^{\star * *}$ & $88.32^{\star * *}$ & $73.70^{\star \star \star}$ & $80.68^{\star * *}$ & $73.27^{\star * *}$ \\
\hline $\mathrm{N} \times \mathrm{T}$ & 1451 & 1451 & 1451 & 1330 & 1330 & 1330 \\
\hline
\end{tabular}

(i) The symbols ${ }^{* *},{ }^{* *}$, and ${ }^{*}$ denote significance at $1 \%, 5 \%$, and $10 \%$ respectively. (ii) The values in parentheses represent the p-values. (iii) $\mathrm{CD}$ is the test statistics presented in [45] for the null hypothesis of independence between cross-sections.

Table 3. Estimate Fixed Effect (FE) of long-term effect based on cross-sectionally enhanced ARDL approach (CS-ARDL), 2002-2015.

\begin{tabular}{|c|c|c|c|c|c|c|}
\hline & \multicolumn{6}{|c|}{ CS-ARDL (FE) } \\
\hline & \multicolumn{3}{|c|}{$1 \mathrm{Lag}$} & \multicolumn{3}{|c|}{2 Lags } \\
\hline & (a) & (b) & (c) & (a) & (b) & (c) \\
\hline \multirow{2}{*}{$\hat{\theta}_{\text {free }_{i t}}$} & $0.018^{* *}$ & & $0.016^{\star}$ & $0.018^{\star *}$ & & $0.016^{* *}$ \\
\hline & $(0.030)$ & & $(0.059)$ & $(0.023)$ & & $(0.049)$ \\
\hline \multirow{2}{*}{$\hat{\theta}_{c p_{i t}}$} & & $0.001^{* *}$ & $0.001^{* *}$ & & $0.001^{* *}$ & $0.001^{*}$ \\
\hline & & $(0.014)$ & $(0.046)$ & & $(0.022)$ & $(0.074)$ \\
\hline \multirow{2}{*}{$\hat{\lambda}$} & $-0.843^{* * *}$ & $-0.833^{* * *}$ & $-0.848^{* * *}$ & $-0.945^{* * *}$ & $-0.927^{* * *}$ & $-0.956^{* * *}$ \\
\hline & $(0.000)$ & $(0.000)$ & $(0.000)$ & $(0.000)$ & $(0.000)$ & $(0.000)$ \\
\hline Test CD & -0.66 & -0.74 & --0.73 & -0.75 & -0.81 & -0.83 \\
\hline $\mathrm{N} \times \mathrm{T}$ & 1209 & 1209 & 1209 & 1209 & 1209 & 1209 \\
\hline
\end{tabular}

(i) The symbols ${ }^{* * *}$, ${ }^{* *}$, and ${ }^{*}$ denote significance at $1 \%, 5 \%$, and $10 \%$ respectively. (ii) The values in parentheses represent the $p$-values. (iii) $\mathrm{CD}$ is the test statistics presented in [45] for the null hypothesis of independence between cross-sections.

economic freedom and economic growth, whether in the presence of the variable control over corruption or not.

In short, our results support the evidence that corruption and a low level of economic freedom negatively affect economic growth. Similar results are found in [23].

\section{Conclusions}

This study estimates the long-term effects of corruption control and economic 
freedom on economic growth of 121 countries through autoregressive distributed lags (ARDL) models. The index of economic freedom used is broad and reflects various aspects of the economy, such as money and inflation, the structure of the economy, the presence of discriminatory taxes and international trade. For an economy to receive a high rating, it must have a stable monetary environment, with freedom for individuals to make their choices, low taxes, greater participation of private enterprise in production and economic openness with low trade barriers.

The results indicate positive long-term effects of corruption control and economic freedom on economic growth. Although the ARDL model and the estimation technique used are robust to endogeneity and other econometric problems, the currently available period is limited. Therefore, one should consider this caveat and read the results of this work as empirical evidence.

However, there is a possibility that corruption may be beneficial to growth in economies with high bureaucracy. Thus, one way to continue this research is to use nonlinear models that allow testing and estimating (endogenously) whether there is a level of corruption or bureaucracy above which the effects on growth are negative, but before that point the corruption's effect is null or even positive on economic growth.

\section{Conflicts of Interest}

The authors declare no conflicts of interest regarding the publication of this paper.

\section{References}

[1] Cieślik, A. and Goczek, Ł. (2018) Control of Corruption, International Investment, and Economic Growth-Evidence from Panel Data. World Development, 103, 323-335. https://doi.org/10.1016/j.worlddev.2017.10.028

[2] Mauro, P. (1997) The Effects of Corruption on Growth, Investment, and Government Expenditure: A Cross-Country Analysis. Corruption and the Global Economy, Institute for International Economics.

[3] Easterly, W. (2005) Can Foreign Aid Save Africa. In: Clemens Lectures, Series 17, Saint John's University, Jamaica, NY.

[4] Dike, V.E. (2005) Corruption in Nigeria: A New Paradigm for Effective Control. Africa Economic Analysis, 24, 1-22.

[5] Mauro, P. (1998) Corruption and the Composition of Government Expenditure. Journal of Public Economics, 69, 263-279. https://doi.org/10.1016/S0047-2727(98)00025-5

[6] Tanzi, V. and Davoodi, H.R. (1997) Corruption, Public Investment, and Growth. IMF Working Papers, 97, 23. https://doi.org/10.5089/9781451929515.001

[7] Tiongson, E., Davoodi, H.R. and Gupta, S. (2000) Corruption and the Provision of Health Care and Education Services. IMF Working Papers.

[8] Reinikka, R. and Svensson, J. (2005) Fighting Corruption to Improve Schooling: Evidence from a Newspaper Campaign in Uganda. Journal of the European Economic Association, 3, 259-267. https://doi.org/10.1162/jeea.2005.3.2-3.259 
[9] Mo, P.H. (2001) Corruption and Economic Growth. Journal of Comparative Economics, 29, 66-79. https://doi.org/10.1006/jcec.2000.1703

[10] Bardhan, P. (1997) Corruption and Development: A Review of Issues. Journal of Economic Literature, 35, 1320-1346. https://www.jstor.org/stable/2729979

[11] Beck, P.J. and Maher, M.W. (1986) A Comparison of Bribery and Bidding in Thin Markets. Economics Letters, 20, 1-5. https://doi.org/10.1016/0165-1765(86)90068-6

[12] Lien, D.H.D. (1986) A Note on Competitive Bribery Games. Economics Letters, 22, 337-341. https://doi.org/10.1016/0165-1765(86)90093-5

[13] Leff, N.H. (1964) Economic Development through Bureaucratic Corruption. American Behavioral Scientist, 8, 8-14. https://doi.org/10.1177/000276426400800303

[14] Leys, C. (1965) What Is the Problem about Corruption? The Journal of Modern African Studies, 3, 215-230. https://doi.org/10.1017/S0022278X00023636

[15] Huntington, S.P. and Fukuyama, F. (2006) Political Order in Changing Societies. Yale University Press, London.

[16] Thach, N.N., Duong, M.B. and Oanh, T.T.K. (2017) Effects of Corruption on Economic Growth-Empirical Study of Asia Countries. Imperial Journal of Interdisciplinary Research, 7, 791-804.

[17] Goldsmith, A.A. (1999) Slapping the Grasping Hand: Correlates of Political Corruption in Emerging Markets. American Journal of Economics and Sociology, 58, 865-883. https://doi.org/10.1111/j.1536-7150.1999.tb03398.x

[18] Paldam, M. (2002) The Cross-Country Pattern of Corruption: Economics, Culture and the Seesaw Dynamics. European Journal of Political Economy, 18, 215-240. https://doi.org/10.1016/S0176-2680(02)00078-2

[19] Shen, C. and Williamson, J.B. (2005) Corruption, Democracy, Economic Freedom, and State Strength: A Cross-National Analysis. International Journal of Comparative Sociology, 46, 327-345. https://doi.org/10.1177/0020715205059206

[20] Billger, S.M. and Goel, R.K. (2009) Do Existing Corruption Levels Matter in Controlling Corruption? Crosscountry Quantile Regression Estimates. Journal of Development Economics, 90, 299-305. https://doi.org/10.1016/j.jdeveco.2008.07.006

[21] Gwartney, J.D., Holcombe, R.G. and Lawson, R.A. (1999) Economic Freedom and the Environment for Economic Growth. Journal of Institutional and Theoretical Economics, 155, 643-663.

[22] Grubel, H. (1998) Economic Freedom and Human Welfare: Some Empirical Findings. The Cato Journal, 18, 287-304.

[23] Hall, J. and Levendis, J. (2017) The Efficient Corruption Hypothesis and the Dynamics between Economic Freedom, Corruption, and National Income. Working Paper Series, No. 17-06, Department of Economics, West Virginia University, Morgantown, WV.

[24] Méon, P.G. and Weill, L. (2010) Is Corruption an Efficient Grease? World Development, 38, 244-259. https://doi.org/10.1016/j.worlddev.2009.06.004

[25] Alenoghena, R.O. and Evans, O. (2015) Corruption Effects on Nigeria: Aggregate and Sectoral Estimates Using VAR. Journal of Economic \& Financial Studies, 3, 41. https://doi.org/10.18533/jefs.v3i02.94

[26] Sharma, C. and Mitra, A. (2019) Corruption and Economic Growth: Some New Empirical Evidence from a Global Sample. Journal of International Development, 31, 691-719. https://doi.org/10.1002/jid.3433

[27] Egger, P. and Winner, H. (2005) Evidence on Corruption as an Incentive for Foreign direct investment. European Journal of Political Economy, 21, 932-952. 
https://doi.org/10.1016/j.ejpoleco.2005.01.002

[28] Lott, J.R. and North, D.C. (1992) Institutions, Institutional Change and Economic Performance. Journal of Policy Analysis and Management, 11, 156. https://doi.org/10.2307/3325144

[29] Friedman, M. (1962) Capitalism and Freedom, University of Chicago Press, Chicago, IL.

[30] Barro, R.J. (1996) Democracy and Growth. Journal of Economic Growth, 1, 1-27. https://doi.org/10.1007/BF00163340

[31] Brunetti, A. (1997) Politics and Economic Growth: A Cross-Country Data Perspective. OECD Publishing, Paris.

[32] Gwartney, J.D., Lawson, R. and Block, W. (1996) Economic freedom of the world, 1975-1995. The Fraser Institute, Toronto.

[33] De Haan, J. and Sturm, J.E. (2000) On the Relationship between Economic Freedom and Economic Growth. European Journal of Political Economy, 16, 215-241. https://doi.org/10.1016/S0176-2680(99)00065-8

[34] Compton, R.A., Giedeman, D.C. and Hoover, G.A. (2011) Panel Evidence on Economic Freedom and Growth in the United States. European Journal of Political Economy, 27, 423-435. https://doi.org/10.1016/j.ejpoleco.2011.01.001

[35] Peev, E. and Mueller, D.C. (2012) Democracy, Economic Freedom and Growth in Transition Economies. Kyklos, 65, 371-407. https://doi.org/10.1111/j.1467-6435.2012.00543.x

[36] Pesaran, M.H. and Smith, R. (1995) Estimating Long-Run Relationships from Dynamic Heterogeneous Panels. Journal of Econometrics, 68, 79-113. https://doi.org/10.1016/0304-4076(94)01644-F

[37] Pesaran, M.H. (1997) The Role of Economic Theory in Modelling the Long Run. The Economic Journal, 107, 178-191. https://doi.org/10.1111/1468-0297.00151

[38] Pesaran, M.H. and Shin, Y. (1999) An Autoregressive Distributed Lag Modelling Approach to Cointegration Analysis. Econometrics and Economic Theory in the 20th Century. In: The Ragnar Frisch Centennial Symposium, Cambridge University Press, Cambridge, 1-31. https://doi.org/10.1017/CCOL521633230.011

[39] Chudik, A. and Pesaran, M.H. (2013) Large Panel Data Models with Cross-Sectional Dependence: A Survey. Federal Reserve Bank of Dallas, Globalization and Monetary Policy Institute Working Papers. https://doi.org/10.24149/gwp153

[40] Pesaran, M.H. (2006) Estimation and Inference in Large Heterogeneous Panels with a Multifactor Error Structure. Econometrica, 74, 967-1012. https://doi.org/10.1111/j.1468-0262.2006.00692.x

[41] Pesaran, M.H. (2015) Testing Weak Cross-Sectional Dependence in Large Panels. Econometric Reviews, 34, 1089-1117. https://doi.org/10.1080/07474938.2014.956623

[42] Yamarik, S. and Redmon, C. (2017) Economic Freedom and Corruption: New Cross-Country Panel Data Evidence. Journal of Private Enterprise, 32, 17-44.

[43] Hall, J.C. and Lawson, R.A. (2014) Economic Freedom of the World: An Accounting of the Literature. Contemporary Economic Policy, 32, 1-19. https://doi.org/10.1111/coep.12010

[44] Gwartney, J., Robert, L. and Hall, J. (2016) Economic Freedom of the World: 2016 Annual Report Vancouver. Fraser Institute, Vancouver.

[45] Pesaran, M.H. (2004) General Diagnostic Tests for Cross Section Dependence in Panels. Iza, 1-42. 